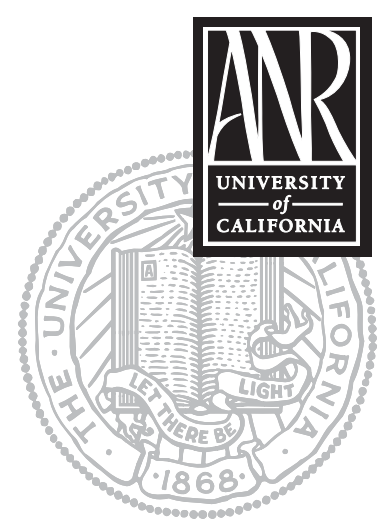

UNIVERSITY OF CALIFORNIA

Division of Agriculture and Natural Resources http://anrcatalog.ucdavis.edu

\title{
NUTRITION AND HEALTH INFO SHEET Facts about Fat
}

NADINE J. KIRKPATRICK, Department of Nutrition, University of California, Davis; CRISTY HATHAWAY, Research Assistant, Department of Nutrition, University of California, Davis; KARRIE HENEMAN, Assistant Project Scientist, Department of Nutrition, University of California, Davis; SHERI ZIDENBERG-CHERR, UC Cooperative Extension Nutrition Science Specialist, Department of Nutrition, University of California, Davis

\section{What are fats?}

In order to understand the functions of fat, as well as the concerns associated with a diet high in fat, it is important to understand its composition. ${ }^{1}$ Fats are a subset of a class of nutrients called lipids, which also includes phospholipids and sterols. Usually when people refer to fats and oils, they are speaking of triglycerides, the most common forms of fat in the diet. Triglycerides come in many sizes and several varieties, but they all share a common structure: a backbone of glycerol to which three fatty acids are attached. While all glycerol molecules are alike, the fatty acids may vary in two ways: length and degree of saturation. ${ }^{1}$

\section{What are fatty acids?}

Three types of fatty acids form the basic chemical units in fat: saturated, monounsaturated, and polyunsaturated. All dietary triglycerides are made up of a mixture of these fatty acid types. ${ }^{1}$

\section{Saturated fatty acids}

These are concentrated in fats from meat and dairy products and in some vegetable fats such as coconut, palm, and palm kernel oils. They are usually solid at room temperature. ${ }^{1}$

\section{Monounsaturated fatty acids}

These are found mainly in olive, peanut, and canola oils. They are liquid at room temperature. ${ }^{1}$

\section{Polyunsaturated fatty acids}

These exist primarily in safflower, sunflower, corn, soybean, and cottonseed oils along with some fish. They are usually liquid at room temperature. ${ }^{1}$

\section{What are trans fatty acids?}

Trans fatty acids are the product of hydrogenating oils, a process that converts liquid fat (vegetable oils) to solid fat (margarine). This method has been used by many food manufacturers because it extends the shelf life of foods, increases resistance to rancidity, and is fairly inexpensive. On average, about 3 percent of total calorie intake in the United States can be attributed to trans fats. ${ }^{2}$

Studies have found that trans fats raise LDL-cholesterol and total cholesterol, as do saturated fats; other findings suggest a correlation between cardiovascular disease and trans fat intake. ${ }^{2,3}$ Due to concern about the rising evidence of this correlation, the Food and Drug Administration (FDA) now requires information about the trans fat content of foods on nutrition food labels. These new labels went into effect on January 1, 2006. 


\section{What functions do fats serve?}

Fat can be found in various forms in the diet and each form can serve a different purpose. ${ }^{1}$ Essential fatty acids (EFAs) are omega- 3 and omega- 6 fatty acids that the human body is not able to create, and must come from food sources. Alpha-linolenic acid (omega-3) and linoleic acid (omega-6) are the two essential fatty acids; they play a key role in the immune system, vision, and cell structure. Good food sources for these essential fatty acids include vegetable oils that can be found in mayonnaise or salad dressings. While uncommon in the United States where fat is abundant, a deficiency in essential fatty acids can result in diarrhea, anemia, and skin problems. Another omega-3 fatty acid, which is not one of the EFAs, is eicosapentaenoic acid. This fatty acid is abundant in fish such as salmon, halibut, and trout.

Triglycerides are mainly responsible for storing energy and insulating the body and its organs. They also transport vitamins that are fat-soluble and contribute to taste and feeling full after eating a meal. Above all, fat supplies energy needed for physical activity. ${ }^{1}$

\section{How much fat should be included in your diet?}

The U.S. Dietary Guidelines 2005 recommend limiting total fat to 20 to 35 percent of total calories and saturated fat to 10 percent of total calories. ${ }^{4}$ According to the 2002 report from the Institute of Medicine's Food and Nutrition Board on Acceptable Macronutrient Distribution Range for Fat, the suggested goal is to maintain a total dietary fat intake of 20 to 35 percent for adults, 30 to 40 percent for children ages 1 to 3 , and 25 to 35 percent for children ages 4 to $18 .{ }^{5}$

\section{When does too much fat become a problem?}

A substantial rise in the prevalence of obesity among children and adults in the United States has been observed. This trend contributes to the population being at greater risk of developing diabetes, high blood pressure, and cardiovascular disease. ${ }^{6}$ The main environmental or lifestyle factors contributing to obesity are overeating and choosing a high-calorie diet in combination with inadequate exercise. ${ }^{7}$ Choosing large or "supersized" portions may lead to overeating. National statistics show that approximately 20 percent of children and adolescents are considered overweight. ${ }^{8}$

\section{What is the relation between fat and Cardiovascular Disease (CVD)?}

While it is essential that our diet include some fat, most health authorities advise that reducing cholesterol and the intake of fat, particularly saturated fat, may reduce the risk for heart disease. The way diet affects blood cholesterol varies among individuals. However, blood cholesterol does increase in most people when they eat a diet high in saturated fat. For adults, a desirable level of blood cholesterol is $200 \mathrm{mg} / \mathrm{dl}$ (milligrams per deciliter) or below. As blood cholesterol increases above this level, greater risk for heart disease occurs. CVD risk can also be increased by having high blood pressure, diabetes, a family history of premature heart disease, being obese, being male, and smoking cigarettes. ${ }^{1}$

Many studies have found that the rate of CVD is very low among individuals and societies that consume large amounts of fish. ${ }^{9}$ Studies on indigenous Alaskans and Japanese populations, for instance, have shown that fish may significantly decrease the possibility of atherosclerosis.

In various studies, omega-3 fatty acids (eicosapentaenoic acid [EPA] and docosahexaenoic acid [DHA]) in fish have been associated with lowering the risk for CVD and mortality ${ }^{10}$ Saturated and trans fats, on the other hand, have been shown to elevate the risk for CVD. ${ }^{12}$ It is important to realize that not all fat is bad or harmful. Consuming high amounts of saturated fat poses a risk, but foods with omega-3 fatty acids can be beneficial.9,11 


\section{What is the relation between fat and cancer?}

There is evidence that diets high in total fat or saturated fatty acids are associated with a higher risk of several cancers, especially of the colon, prostate, and breast. Given the present recommendations to reduce total fat and saturated fatty acids, many people may go to extremes and try to include only polyunsaturated fatty acids in their diet. The effects of following such a diet are unknown.

The preparation of meats is also of importance. Deep-frying foods or charbroiling them until they have a burned surface may pose a risk to the consumer since this process results in fat oxidization, which has been shown to increase the risk for developing cancer. ${ }^{12}$ Thus, the best advice is dietary moderation.

\section{How can fat intake be calculated?}

You can determine the number of grams of fat that provide 30 percent of calories in the daily diet as follows:

- Multiply the total calories for one day by 0.30 to get the recommended amount of calories from fat per day. (Example: 1,800 calories $\times 0.30=540$ calories from fat. So if you consume 1,800 calories per day, about 540 calories should come from fat.)

- Divide calories from fat per day by 9 (each gram of fat contains 9 calories) to get grams of fat recommended per day. (Example: 540 calories from fat divided by $9=60$ grams of fat.)

\section{What are some ways to control fat intake?}

According to the American Heart Association, consumers should limit their intake of foods rich in saturated fats, including tropical oils such as palm and coconut oil. ${ }^{13}$

Here are a few simple dietary suggestions to accomplish this goal:

- Consume 7 to 9 servings of fruits and vegetables each day to partially replace fatty foods.

- Add a mixture of grain products to the diet.

- Replace fatty meats with skinless chicken, fish, or other lean meats, and drink fat-free or low-fat milk instead of whole milk.

\section{What are some food sources for different kinds of fat?}

- Saturated fats Meat, poultry, whole-dairy products, and coconut and palm oils ${ }^{11}$

- Monounsaturated fats Olive and canola oil, peanuts, and avocados ${ }^{11}$

- Polyunsaturated fats Safflower, sunflower, corn, and soybean-oil, as well as fish (omega-3) ${ }^{11}$

- Trans fatty acids Bakery products, crackers, chips, and dairy and meat products ${ }^{2,3}$

- Omega-3 and omega-6 fatty acids Fish such as salmon and trout, salad dressings, and vegetable oils ${ }^{1}$

\section{What is olestra?}

Olestra is a noncaloric fat substitute found in some low-calorie snack foods such as certain potato chips. Products made with olestra are much lower in calorie content than ones made with regular fat. ${ }^{14}$ Following concern that consuming high amounts of olestra would result in intestinal problems that could reduce the absorption of the 
fat-soluble vitamins (A, D, E, and K), current research has shown that the consumption of olestra does not cause intestinal problems or affect serum levels of fat-soluble vitamins. One potential problem with the introduction of fat-replacement products is over-consumption, since these products are considered "fat free." For example, instead of eating fifteen regular potato chips, consumers may feel free to eat thirty olestra potato chips. Since fat-substitute products still have calories (despite a common misconception to the contrary), the result may be that a similar amount of calories or even more calories are consumed. ${ }^{14}$ What is the cholesterol, total fat, and saturated fat
content of some common foods?15

\begin{tabular}{|c|c|c|c|}
\hline & $\begin{array}{l}\text { Cholesterol } \\
\text { (mg) }\end{array}$ & $\begin{array}{l}\text { Total fat } \\
\text { (g) }\end{array}$ & $\begin{array}{c}\text { Saturated } \\
\text { fat } \\
\text { (g) }\end{array}$ \\
\hline \multicolumn{4}{|l|}{ Dairy products } \\
\hline \multicolumn{4}{|l|}{ milk, 1 cup } \\
\hline $3.25 \%$ fat & 34.2 & 8.2 & 5.0 \\
\hline $2 \%$ fat & 19.5 & 4.7 & 2.9 \\
\hline $1 \%$ fat & 9.8 & 2.6 & 1.6 \\
\hline skim (nonfat) & 4.9 & 0.4 & 0.3 \\
\hline \multicolumn{4}{|l|}{ yogurt, 1 cup } \\
\hline nonfat plain & 4.9 & 0.4 & 0.3 \\
\hline low-fat, plain & 14.7 & 3.8 & 2.5 \\
\hline low-fat, fruit flavored & 12.3 & 2.8 & 1.9 \\
\hline \multicolumn{4}{|l|}{ Fats, oils, sweets } \\
\hline butter, 1 tbsp & 31.1 & 11.5 & 7.2 \\
\hline margarine, 1 tsp & 0.0 & 3.8 & 0.7 \\
\hline mayonnaise (regular), 1 tbsp & 8.1 & 11.0 & 1.6 \\
\hline sour cream, 1 tbsp & 5.3 & 2.5 & 1.6 \\
\hline cream cheese, 1 tbsp & 16.0 & 5.1 & 3.2 \\
\hline cheesecake (9 in), $1 / 12(99 \mathrm{~g})$ no bake & 28.7 & 12.6 & 6.6 \\
\hline \multicolumn{4}{|l|}{ Meat, poultry, fish, and eggs } \\
\hline prime rib, 3 oz & 72.3 & 28.2 & 11.7 \\
\hline beef liver, braised, $3 \mathrm{oz}$ & 330.7 & 4.2 & 1.6 \\
\hline \multicolumn{4}{|l|}{ lean cut (eye of round), $3 \mathrm{oz}$} \\
\hline lean and fat & 61.2 & 10.8 & 4.2 \\
\hline lean only & 58.7 & 4.2 & 1.5 \\
\hline \multicolumn{4}{|l|}{ ground beef, cooked, 3 oz patty } \\
\hline regular ( $75 \%$ lean and $25 \%$ fat) & 76.7 & 15.9 & 6.1 \\
\hline extra lean ( $95 \%$ lean and $5 \%$ fat) & 64.6 & 5.6 & 2.4 \\
\hline \multicolumn{4}{|l|}{ chicken, light and dark meat, roasted } \\
\hline with skin (178g) & 156.6 & 24.2 & 6.7 \\
\hline without skin (146g) & 129.9 & 10.8 & 3.0 \\
\hline \multicolumn{4}{|l|}{ tuna, canned, 3 oz } \\
\hline in oil & 26.4 & 6.9 & 1.4 \\
\hline in water & 35.7 & 2.5 & 0.7 \\
\hline \multicolumn{4}{|l|}{ shrimp, steamed } \\
\hline 4 large & 42.9 & 0.2 & 0.1 \\
\hline \multicolumn{4}{|l|}{ eggs, large, cooked, 1} \\
\hline yolk & 212.0 & 5.3 & 1.6 \\
\hline white & 0.0 & 0.0 & 0.0 \\
\hline
\end{tabular}

\section{REFERENCES:}

1. Wardlaw, G. M. 2003. Contemporary nutrition: Issues and insights. New York: McGraw-Hill.

2. Tarrago-Trani, M. T., K. M. Phillips, L. E. Lemar, and J. M. Holden. 2006. New and existing oils and fats used in products with reduced trans-fatty acid content. J Am Diet Assoc 106:867-880.

3. Dausch, J. G. 2002. Trans-fatty acids: A regulatory update. J Am Diet Assn 102(1): 18, 20.

4. U.S. Department of Agriculture and U.S. Department of Health and Human Services. 2005. Dietary Guidelines for Americans, 2005. Dietary Guidelines for Americans Web site, http://www.health.gov/ dietaryguidelines/dga2005/document/ pdf/DGA2005.pdf.

5. Institute of Medicine. 2002. Dietary reference intakes for energy, carbohydrate, fiber, fat, fatty acids, cholesterol, protein, and amino acids (macronutrients). Washington, DC: National Academy Press. National Academy Web site, www.nap.edu.

6. Barlow, S. E., F. L. Trowbridge, W. J. Klish, and W. H. Dietz. 2002. Treatment of child and adolescent obesity: Reports from pediatricians, pediatric nurse practitioners, and registered dietitians. Pediatrics 110 (1 SUPPS): 229-235.

7. Dube, M. G., E. Beretta, H. Dhillon, N. Ueno, P. S. Kalra, and S. P. Kalra. 2002. Central leptin gene therapy blocks high-fat diet-induced weight gain, hyperleptinemia, and hyperinsulinemia: Increase in serum ghrelin levels. Diabetes 51(6): 1729-1736. 
8. Ogden, C. L., M. D. Carroll, L. R. Curtin, M. A. McDowell, C. J. Tabak, and K. M. Flegal. 2006. Prevalence of overweight and obesity in the United States, 1999-2004. JAMA 295:1549-1555.

9. Hu, F. B., L. Bronner, W. C. Willett, M. J. Stampfer, K. M. Rexrode, C. M. Albert, D. Hunter, and J. E. Manson. 2002. Fish and omega-3 fatty acid intake and risk of coronary heart disease in women. J Am Med Assn 287(14): 1815-1821.

10. Panagiotakos, D. B., A. Zeimbekis, V. Boutziouka, M. Economou, G. Kourlaba, P. Toutouzas, and E. Polychronopoulos. 2007. Long-term fish intake is associated with better lipid profile, arterial blood pressure, and blood glucose levels in elderly people from Mediterranean islands (MEDIS epidemiological study). Med Sci Monit 13(7): CR307-312.

11. U.S. National Library of Medicine. 2001. Medical Encyclopedia: Fat. National Library of Medicine MEDLINE Plus Web site, www.nlm.nih.gov/medlineplus/ ency/article/002468.htm.

12. Tareke, E., P. Rydberg, P. Karlsson, S. Eriksson, and M. Tornqvist. 2002. Analysis of acrylamide, a carcinogen formed in heated foodstuffs. J Agric Food Chem 50(17): 4998-5006.

13. American Heart Association. 2003. American Heart Association Web site, http://www.americanheart.org/presenter.jhtml?identifier=4779.

14. Patterson, R. E., A. R. Kristal, J. C. Peters, M. L. Neuhouser, C. L. Rock, L. J. Cheskin, D. Neumark-Sztainer, and M. D. Thornquist. 2000. Changes in diet, weight, and serum lipid levels associated with olestra consumption. Arch Intern Med 160(17): 2600-2604.

15. USDA (U. S. Department of Agriculture). 2002. USDA Nutrient Data Laboratory Web site, http://www.ars.usda.gov/main/site_main.htm?modecode=12354500.

\section{METRIC CONVERSIONS}

\begin{tabular}{|l|c|c|c|}
\hline English & $\begin{array}{c}\text { Conversion factor for } \\
\text { English to metric }\end{array}$ & $\begin{array}{c}\text { Conversion factor for } \\
\text { metric to English }\end{array}$ & Metric \\
\hline grain & 64.80 & 0.015 & milligram (mg) \\
\hline fluid ounce (fl oz) & 29.57 & 0.034 & milliliter (ml) \\
\hline fluid ounce (fl oz) & 2.96 & 0.0034 & deciliter (dl) \\
\hline ounce (oz) & 28.35 & 0.035 & gram (g) \\
\hline teaspoon (tsp) & 4.93 & 0.20 & milliliter (ml) \\
\hline tablespoon (tbsp) & 14.79 & 0.067 & milliliter (ml) \\
\hline cup & 236.60 & 0.004 & milliliter (ml) \\
\hline
\end{tabular}

\section{FOR FURTHER INFORMATION}

To order or obtain printed ANR publications and other products, visit the ANR Communication Services online catalog at http://anrcatalog.ucdavis.edu. You can also place orders by mail, phone, or FAX, or request a printed catalog of our products from

University of California

Agriculture and Natural Resources

Communication Services

6701 San Pablo Avenue, 2nd Floor

Oakland, California 94608-1239

Telephone: (800) 994-8849 or (510) 642-2431

FAX: (510) 643-5470

E-mail inquiries: danrcs@ucdavis.edu 


\section{UC REVIEWED}

An electronic version of this publication is available on the ANR Communication Services Web site at http://anrcatalog.ucdavis.edu.

This publication has been anonymously peer reviewed for technical accuracy by University of California scientists and other qualified professionals. This review process was managed by the ANR Associate Editor for Food and Nutrition.

\section{Publication 8136}

ISBN-13: 978-1-60107-493-5

(C) 2008 The Regents of the University of California, Division of Agriculture and Natural Resources

All rights reserved.

No part of this publication may be reproduced, stored in a retrieval system, or transmitted, in any form or by any means, electronic, mechanical, photocopying, recording, or otherwise, without the written permission of the publisher and the authors.

The University of California prohibits discrimination or harassment of any person on the basis of race, color, national origin, religion, sex, gender identity, pregnancy (including childbirth, and medical conditions related to pregnancy or childbirth), physical or mental disability, medical condition (cancer-related or genetic characteristics), ancestry, marital status, age, sexual orientation, citizenship, or status as a covered veteran (covered veterans are special disabled veterans, recently separated veterans, Vietnam era veterans, or any other veterans who served on active duty during a war or in a campaign or expedition for which a campaign badge has been authorized) in any of its programs or activities. University policy is intended to be consistent with the provisions of applicable State and Federal laws.

Inquiries regarding the University's nondiscrimination policies may be directed to the Affirmative Action/Staff Personnel Services Director, University of California, Agriculture and Natural Resources, 1111 Franklin Street, 6th Floor, Oakland, CA 94607-5201, (510) 987-0096. For information about ordering this publication, telephone 1-800-994-8849.

pr-1/08-LR/RW 